\title{
Pemberdayaan Petani Padi di Desa Mas, Ubud, Bali Melalui Pelatihan Pembuatan Lulur Tradisional Berbahan Dasar Beras
}

\author{
A A Sagung Mirah Padmadewi*1, Luh Putu Mahyuni² \\ 1,2Fakultas Ekonomi dan Bisnis, Universitas Pendidikan Nasional \\ *e-mail : sagungmirahpadmadewi@gmail.com¹, mahyuniluhputu@undiknas.ac.id²
}

\begin{abstract}
Rice farmers roles are very significant in establishing national food security. However, due to weather that is often uncontrolled, affecting the quantity and quality of the harvest, the welfare of rice farmers is still difficult to improve. As an effort to improve the welfare of rice farmers, this community outreach activity seeks to assist farmers, especially in Mas Village - Ubud, increase the added value of their harvests by providing training on making beauty scrubs made from rice and turmeric. The training covers not only the production process, but also packaging and labeling methods. Exploration of potentials and problems was done through the process of observation and interviews. Then the planning process of training activities, training implementation, and evaluation process was carried out, to achieve the goals of community outreach activities. This community outreach activity provides new knowledge and skills for rice farmers and their families in processing rice into traditional scrubs. These new skills are expected to be able to help improve the welfare of rice farmers in Mas Village, especially during this pandemic. This community outreach activity paper contributes to the literature, by offering insight into how the welfare of rice farmers could be improved by providing trainings to increase the added value of agricultural production. In addition, the findings of this community outreach activity can also be applied to different contexts, so that this paper also offers significant practical contribution.
\end{abstract}

Keywords: Value-added agricultural products, Rice-based traditional scrubs, Packaging and labeling strategy

\begin{abstract}
Abstrak
Petani padi merupakan salah satu ujung tombak ketahanan pangan nasional. Akan tetapi, akibat cuaca yang seringkali tidak terkendali, mempengaruhi kuantitas dan kualitas hasil panen, kesejahteraan petani padi masih sulit ditingkatkan. Sebagai salah satu upaya meningkatkan kesejahteraan petani padi, kegiatan pengabdian ini berupaya membantu petani, khususnya di Desa Mas - Ubud, meningkatkan nilai tambah hasil panennya dengan memberikan pelatihan pembuatan lulur kecantikan berbahan dasar beras dan kunyit. Pelatihan mencakup tidak hanya proses produksi, melainkan juga pengemasan hingga pembuatan label. Penggalian potensi dan masalah dilakukan melalui proses observasi dan wawancara. Kemudian dilakukan proses perencanaan kegiatan pelatihan, pelaksanaan pelatihan, dan proses evaluasi, untuk mencapai tujuan kegiatan pengabdian. Kegiatan pengabdian ini memberi pengetahuan dan keterampilan baru bagi petani padi dan keluarganya dalam pengolahan beras menjadi lulur tradisional. Keterampilan baru ini diharapkan akan dapat membantu meningkatkan kesejahteraan petani padi di Desa Mas, terutama pada masa pandemi ini. Kegiatan pengabdian ini diharapkan akan dapat menjadi tambahan referensi terkait upaya peningkatan nilai tambah produksi pertanian dan peningkatan kesejahteraan petani. Selain itu, temuan kegiatan pengabdian ini juga dapat diaplikasikan pada konteks yang berbeda, sehingga akan dapat memberikan kontribusi praktis yang signifikan.
\end{abstract}

Kata kunci: Nilai tambah hasil pertanian, Lulur tradisional berbahan dasar beras, Strategi pengemasan dan pelabelan

\section{PENDAHULUAN}

\subsection{Analisa situasi}

Petani padi merupakan pelaku yang melakukan usaha taninya di lahan sawah yang dikelola berdasarkan kemampuan lingkungan biologis, sosial ekonomi, dan sumber daya alam yang dimiliki menghasilkan padi (Aldillah, 2016). Desa Mas Ubud ini merupakan Desa yang cukup luas yang terletak di Kabupaten Gianyar, Bali. Desa Mas ubud ini juga dikenal akan lahan 
persawahannya, pariwisatanya dan kerajinan ukirnya, terdapat cukup banyak tempat persembahayangan Agama Hindu (Pura), permukiman masyarakat yang masih kental akan tradisionalnya dan lahan kuburan di Desa Mas ini cukup luas dan besar dengan bagian luar yang dibangun dengan bantu alam yang tinggi dan terawat membuat siapaun yang melewatinya terlihat menarik. Dengan memilih Lokasi kegiatan pengabdian masyarakat di Desa Mas Ubud Gianyar, Bali ini. Kegiatan pengabdian kepada masyarakat dilakukan untuk memberi pengetahuan kepada petani mengenai potensi pemanfaatan beras menjadi lulur tradisional dan memberi pelatihan terkait cara pembuatan lulurt tradisional berbahan dasar beras dan kunyit.

Desa Mas Ubud merupakan Desa penghasil sumber daya alam berupa padi yang cukup melimpah dengan potensi tersebut kami ingin memaparkan permasalahan yang terjadi disaat pandemi covid-19 ini yaitu permasalahan yang terjadi kepada pelaku petani padi (Yulmardi \& Erfit, 2018). Mengingat saat ini bahwa petani padi belum dapat mengoptimalkan pendapatannya dari pertanian padi karena di masa pandemi ini merupakan titik dimana susahnya petani padi untuk menjual hasil panen yang dikarenakan hasil panen padi tersebut berkurangnya kualitas padi sehingga dapat menurunkan harga beras yang di karena terdapat perubahan iklim yang tidak menentu mengakibatkan petani susah untuk mendapatkan hasil padi yang terbaik. Dengan menciptakan ide kreatif atau invoasi baru yang sebelumnya belum pernah dilakukan di Desa Mas Ubud yaitu pembuatan lulur tradisional berbahan dasar beras. Dengan membuat inovasi lulur tradisional berbahan beras ini di harapkan hasil panen padi yang memiliki kualitas kurang baik tidak terbuang sia-sia tetapi digunakan dengan baik dan dalam potensi pengolahan beras menjadi produk dengan memiliki nilai tambah dan nilai jual lebih tinggi, salah satunya dengan diolah menjadi lulur tradisional.

Beras merupakan makanan pokok masyarakat Indonesia yang dimanfaatkan sebagai makanan utama yang diolah menjadi nasi, selain merupakan makanan pokok beras juga bisa digunakan sebagai bahan dasar untuk kecantikan kulit sudah sudah dipercayai sejak dulu. Beras memiliki khasiat yang baik untuk kecantikan dan kesehatan kulit yaitu meningkatkan produksi kolagen yang bermanfaat untuk membantu meningkatkan kesehatan kulit, memberikan efek elastisitas dan hidrasi pada kulit (Yuliansari Arita, 2020). Kandungan yang terdapat pada beras yaitu gamma oryzanol, kandungan ini memiliki manfaat yang baik untuk kecantikan kulit sehingga dapat memperbaharui pembentukan pigmen melanin, antioksidan dan efektif untuk menangkal sinar ultraviolet yang membahayakan kulit. Dengan rajin merawat kulit secara teratur dan menggunakan produk lulur yang bagus contohnya produk lulur bahan alami yang aman digunakan tanpa efek samping. Dengan rajin merawat kulit merupakan langkah awal untuk menjaga kesehatan kulit maupun kecantikan kulit.

Selain mengunakan bahan dasar beras pada produk lulur ini kami menambah 1 produk alami agar dapat lebih memaksimalkan efek dari lulur tradisional ini yaitu penambahan bahan kunyit. Selama ini masyarakat kurang mengetahui manfaat kunyit lainnya yitu dapat digunakan sebagai produk lulur tradisional. Masyarakat hanya mengetahui bahan kunyit sebagai obat tradisional saja yang diolah menjadi jamu, obat penurun panas dalam dan bahan masakan sehari - hari (Erlinawati \& Dwiyanti, 2018). Adapun manfaat kunyit untuk kecantikan kulit yaitu bermanfaat untuk antioksidan, melembabkan kulit, anti inflamasi dan antiseptik yang membantu mengatasi permasalahan jerawat di kulit dan mengatasi pigemntasi dan dapat mencerahkan kulit (Rahmadevi et al., 2020).

Kegiatan pengabdian kepada masyarakat dilakukan untuk memberi pengetahuan kepada petani mengenai potensi pemanfaatan beras menjadi lulur tradisional dan memberikan pelatihan terkait cara pembuatan lulur tradisional berbahan beras dan kunyit.

\subsection{Permasalahan Mitra}

a. Permasalahan dari sisi produksi

Permasalahan yang di hadapi oleh mitra sehubung dengan aspek produksi antara lain: 
1. Ketika panen, padi yang di hasilkan oleh petani memiliki kualitas yang kurang baik akibat cuaca.

2. Mitra belum mempunyai kemampuan dan keterampilan untuk membuat lulur tradisional dari bahan dasar Beras.

b. Permasalahan dari sisi manajemen

Mitra kurang mampu dalam melakukan strategi pengemasan dan label atau merek yang baik, unik dan menarik.

\subsection{Permasalahan prioritas yang disepakati bersama}

- Aspek produksi

1. Memberikan informasi kepada mitra mengenai pembuatan, kandungan yang terdapat pada beras dan tambahan bahan alami kunyit pembuatan lulur tradisional.

2. Menjelasakan bagaimana cara pembuatan lulur tradisional.

\section{- Aspek manajemen}

Merancang kemasan produk lulur tradisional yang baik, aman, unik, menarik, ramah lingkungan dan merancang label atau merek yang menarik.

\subsection{Kajian Literatur}

Pada sistem pertanian di Indonesia, padi masih menjadi komoditas strategis yang telah mendapatkan prioritas dalam pembangunan sosial. Mengingat Beras merupakan bahan pangan pokok utama yang dikonsumsi hampir seluruh masyarakat Indonesia (Puspitasari, 2020). Kebutuhan permintaan beras akan semakin meningkat di karenakan jika pertumbuhan penduduk yang terus meningit (Santoso, M. Ramaddan Julianti, 2018). Dengan adanya permasalahan yang terjadi disaat pandemi covid 19 ini yaitu permasalahan yang terjadi kepada pelaku petani padi dimana mengingat saat ini merupakan titik dimana susahnya petani untuk memasarkan hasil panen disertai iklim yang tidak menentu mengakibatkan petani susah untuk mendapatkan hasil padi yang terbaik. Dengan menciptakan ide kreatif "Lulur Tradisional Berbahan Dasar Beras".

Lulur adalah suatu produk skin care yang digunakan untuk merawat tubuh, mengangkat sel kulit mati sehingga membuat kulit lebih bersih, kencang, dan wangi. Lulur biasanya menggunakan bahan bahan alami seperti beras, kunyit, kopi, madu dan lulur memiliki tekstur yang kasar sehinnga efektif mengangkat sel kilit mati di tubuh Banyak wanita yang melakukan perawatan kulit dengan perawatan luluran (Rachmawati et al., 2021). Manfaat dari luluran yaitu mengangkat sel kulit mati, mencerahkan kulit, melembapkan kulit, menghaluskan dan melembutkan kulit, mencegah penuaan dini, dan relaksasi. Kemasan adalah bungkus atau pelindung, disederhanakan menjadi suatu benda yang dapat digunakan untuk membungkus dan melindungi suatu barang agar lebih rapi, bersih, aman. Kemasan ini mempunyai peranan sangat penting dalam mempertahankan mutu dan keamanan barang (Meila Sari \& Darmawan, 2020). Selain itu pemilihan kemasan yang baik atau menarik dapat meningkatkan daya tarik produk di pasaran. Kemasan yang kita gunakan untuk produk lulur tradisional ini yaitu standing pouch dari kertas, dengan pemilihan kertas coklat salah satu pilihan yang baik karena ramah lingkungan. Kemasan ramah lingkungan merupakan kemasan yang menggunakan bahan-bahan yang muda diurai, bisa di daur ulang dan tidak berbahaya bagi lingkungan maupun manusia. Saat ini kemasan ramah lingkungan juga sebagai tren modern dijaman sekarang ini di kalangan penjual contohnya seperti penjualan Lulur Tradisional. Kemasan ramah lingkungan atau segala hal yang bernuansa natural, sedang tren dan tampak terlihat menarik serta estetik (Bahar et al., 2021).

\section{METODE}

Jenis penelitian yang digunakan untuk kegiatan pengabdian kepada masyarakat adalah Penelitan kualitatif eksperimen. Penelitian eksperimen adalah penelitian yang dilakukan dengan cara mencoba membuat sesuatu yang baru untuk mendapatkan hasil yang dapat dipastikan Dan 
pengambilan sampel pada penelitian kualitatif adalah non-probability sampling dengan pendekatan purposive sampling dimana informasi yang didapat memiliki kualitas secara mendalam karena informan yang dipilih memiliki status dan pengalaman sehingga memiliki pengetahuan khusus dalam mengemukakan informasi. Teknik pengumpulan data yang digunakan dalam penelitian ini yaitu wawancara semi terstruktur.

\subsection{Observasi}

Observasi dilakukan dengan menelusuri wilayah pertanian padi di sekitar Desa Mas Ubud. Dimana observasi ini bertujuan untuk mengetahui apa saja potensi Desa Mas Ubud yang bisa disempurnakan dan memecahkan masalah yang ada di Desa Mas Ubud. Hasil observasi yang dilakukan terdapat potensi yang bisa dikembangkan di Desa Mas Ubud adalah pemberdayaan petani padi dan lingkungan dengan membuat ide kreatif Lulur Tradisional dan bahan dasar beras.

\subsection{Wawancara}

Selain melakukan observasi, metode lainnya yang dilakukan dalam pengabdian ini adalah dengan melakukan wawancara bersama Bapak nyoman selaku petani padi di Desa Mas Ubud. Wawancara ini dilakukan untuk mengetahui lebih lanjut permasalahan yang umumnya dihadapi oleh pemberdayaan padi dan lingkungan di Desa Mas Ubud Setelah melakukan wawancara diketahui permasalahan yang ada yaitu kurang optimalnya hasil panen padi karena faktor cuaca yang tidak menentu. observasi dan wawancara dengan salah satu petani padi, untuk mencari solusi dari permasalahan yang selama ini dihadapi dibuat kesepakatan untuk mengolah hasil panen padi.

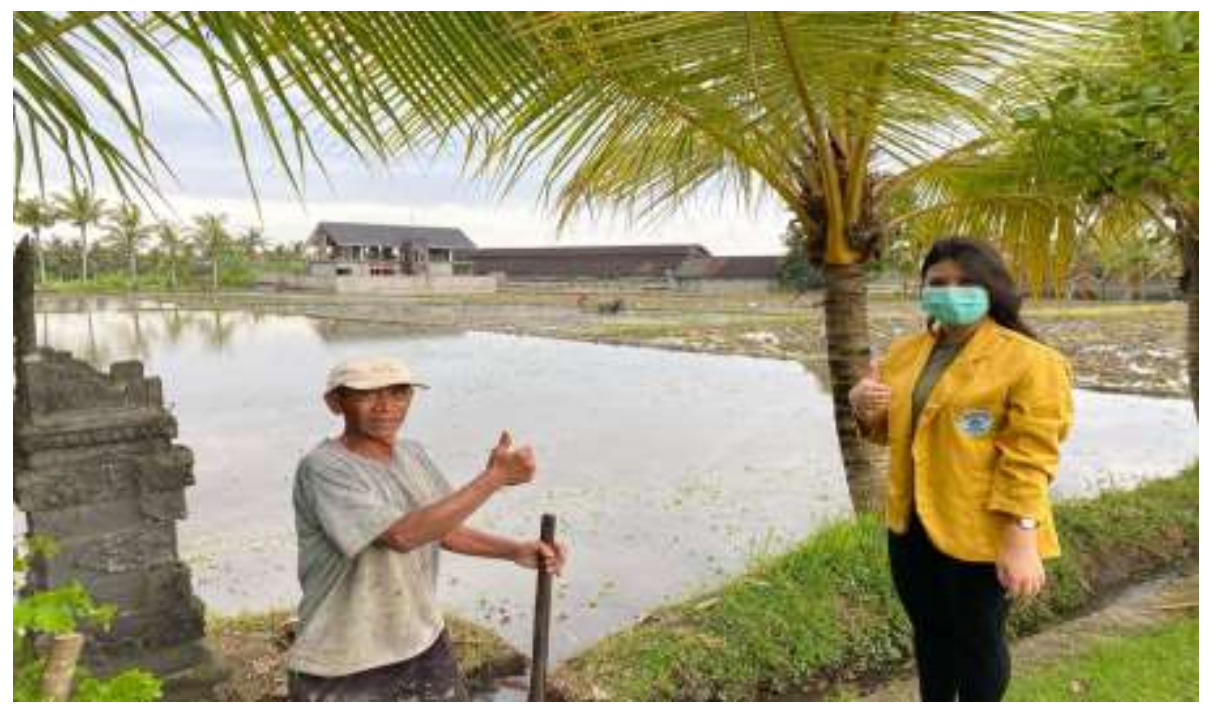

Gambar 1. Foto bersama Bapak Wayan selaku petani padi di Desa Mas

\subsection{Perencanaan dan Persiapan}

Kegiatan perencanaan dan persiapan merupakan hal yang penting sebelum melakukan segala sesuatu. Pada tahap ini kami Langsung melakukan observasi di Persawahan Padi Desa Mas Ubud untuk melihat masalah apa saja yang muncul di Desa Mas Ubud tersebut. Didampingi oleh salah satu mitra, dalam diskusi yang sudah kami lakukan terdapat permasalahan yang muncul terkait dengan keterbatasan pengetahuan mengenai pengolahan Beras sebagai bahan dasar pembuatan Lulur Tradisional, yang mitra ketahui beras biasanya selain menjadi makanan pokok atau sumber karbohidrat utama bisa dibuat menjadi aneka olahan makanan ringan atau snack. Kemudian kami memberikan solusi permasalahan tersebut yaitu dengan pemberian informasi terkait pembuatan Lulur Tradisional berbahan dasar Beras dengan menciptakan produk baru yang kreatif dan inovatif. Produk Lulur Tradisional juga diberikan strategi pengemasan dan pemberian label atau merek yang menarik, unik dan ramah lingkungan agar mampu 
meningkatkan nilai jual. Setelah disepakati kedua belah pihak untuk melakukan kegiatan, maka adapun hal-hal yang harus persiapkan, yaitu: pengolahan padi menjadi beras.

Sejak dulu pengolahan padi sudah di lakukan hingga saat ini terus berkembang baik itu alat-alat ataupun pengolahan dari padi tersebut. Sejak dulu padi mengalami banyak melewati perjalanan, proses, produktifitas dari tanaman padi tersebut dilihat dari perkembangan teknologi. Saat dahulu sebelum ditemukan ataupun adanya alat-alat mekanisasi pertanian berupa motor bakar, para petani menggunakan alat sederhana dalam proses pengolahan seperti misalkan cangkul, sengkuit, ani-ani, sabit, dan lain sebagainya. Namun sekarang setelah kemajuan teknologi terkini, para petani di mudahkan dengan adanya alat-alat mekanisasi pertanian seperti, power threser untuk perontokan bulir padi, mesin pemotong rumput sebagai pengganti sengkuit, reaper sebagai pengganti sabit, dan lain sebagainya. Semua teknologi tersebut diciptakan ataupun di buat untuk mempermudah pekerjaan manusia terutama petani terutama pengolahan serta pasca panen (Ayu Putri Chandra, Ameilia Zuliyanti Siregar, 2020).

Teknologi saat ini identik dengan penggunaan-penggunaan alat bermesin modern yang terus membaharui semata-mata untuk mempermudah pekerjaan manusia, penggunaan alat-alat tersebut tentunya akan mempermudah, efisien dan berdampak baik ataupun positif terhadap hasil dari produk olahan (Hariyanto et al., 2020). Setelah pemanenan padi dilakukan dan diselesaikan, selanjutnya terdapat tahap-tahapan proses gabah menjadi beras (Trisnawan et al., 2019). Proses pengolahan padi di jaman era modern ini menggunakan peralatan atau mesin teknologi yang canggih dan menghemat waktu.

Tahap - tahap pengolahan padi:

1. Penumpukan dan pengumpulan

Merupakan tahap penanganan pasca panen setelah padi dipanen dengan menggunakan alas dan wadah pada saat penumpukan dapat menekan kehilangan hasil anatara $0,94 \%-$ 2,36\%.

2. Perontokan

Perontokan merupakan tahap penanganan pasca panen setelah pemotongan, penumpukan, dan pengumpulan padi.

3. Penjemuran

Sedudah dirontokkan gabah kemudian dijemur di lamporan. Lamporan adalah suatu lantai semen yang dibuat agak tinggi di bagian tengahnya dengan saluran air diantaranya untuk mencegah berkumpulnya air hujan. Praktek penjemuran yang baik adalah dengan menggunakan alas tikar atau plastik/terpal pada lantai sehingga gabah pada lapisan dasar tidak terkena panas yang berlebihan akibat pemanasan lantai semen, selain memudah untuk ditutupi dan diangkut ke gudang dengan cepat bila sewaktu-waktu turun hujan selama penjemuran.

4. Penggilingan

Sebelum digiling, gabah biasanya dibersihkan dari segala kotoran seperti jerami, kayu, pecahan batu, logam dan sebagainya. Kotoran-kotoran lunak seperti jerami akan mengurangi kapasitas giling, sedangkan kotoran-kotoran keras seperti batu akan merusak mesin penggiling. Selanjutnya, gabah dimasukkan ke mesin pemecah kulit. Proses ini mengelupaskan sekam dari gabah. Hasil biji beras pada proses ini yang dikenal dengan beras pecah kulit atau beras cokelat. Biji beras masih memiliki lapisan kulit ari (aleurone dan pericarp) yang dikenal dengan istilah bekatul. Mesin pemecah kulit/sekam gabah kering giling berfungsi

untuk memecahkan dan melepaskan kulit gabah.

5. Penyosohan

Selanjutnya beras pecah kulit mengalami proses penyosohan yang dilakukan menggunakan mesin penyosoh atau disebut juga mesin pemutih. Hasil dari proses penyosohan adalah beras putih yang siap dipasarkan atau dimasak.

6. Penyimpanan 
Penyimpanan merupakan tindakan untuk mempertahankan beras agar dalam keadaan baik dalam jangka waktu tertentu. Penyimpanan beras bisa dengan cara system curah dan juga dengan system kemasan atau wadah seperti karung plastik, karung goni dan sebagainya.

Seperti yang telah dijelaskan diatas proses Padi menjadi Beras, proses selanjutnya yaitu pembuatan beras menjadi tepung beras sebagai bahan dasar lulur tradisional. Dalam melakukan proses pembuatan tepung beras disini kami membuat tekstur dari tepung beras tidaklah dibuat sehalus mungkin melainkan masih terdapat tekstur bulir bulir beras yang kasar agar lulur tradisional lebih efektif digunakan untuk menggangkat sel kulit mati di kulit tubuh kita.

\subsection{Pelaksanaan Kegiatan}

Kegiatan pelaksanaan pembuatan produk lulur tradisional ini dilaksanakan sesuai dengan jadwal yang telah ditentukan dan disepakati bersama oleh kedua belah pihak. Kegiatan pengabdian kepada masyarakat ini dilakukan dengan metode pelatihan dan eksperimen yaitu penelitian sesungguhnya.

\section{- Perencanaan dan persiapan}

Perencanaan yang dilakukan oleh mahasiswa adalah memikirkan konsep alat dan bahan serta bagaimana pengemasan yang baik dan pemberian logo pada proses produksi produk lulur tradisional tepung beras dan bubuk kunyit. Adapun proses perencaan dan persiapan sebagai berikut:

1. Persiapan pembuatan lulur tradisional tepung beras dan bubuk kunyit. Hal-hal yang perlu dipersiapkan yaitu:

- Alat yang digunakan pada pembuatan lulur harus dalam keadaan bersih, baik dan tidak rusak, yaitu baskom kecil, baksom besar, pisau, blender,

- Persiapan Bahan Bahan-bahan yang akan digunakan yaitu: Beras dan Kunyit

2. Tahap Proses pembuatan tepung beras

- Memilih beras yang akan dijadikan tepung beras

- Beras dicuci sampai bersih

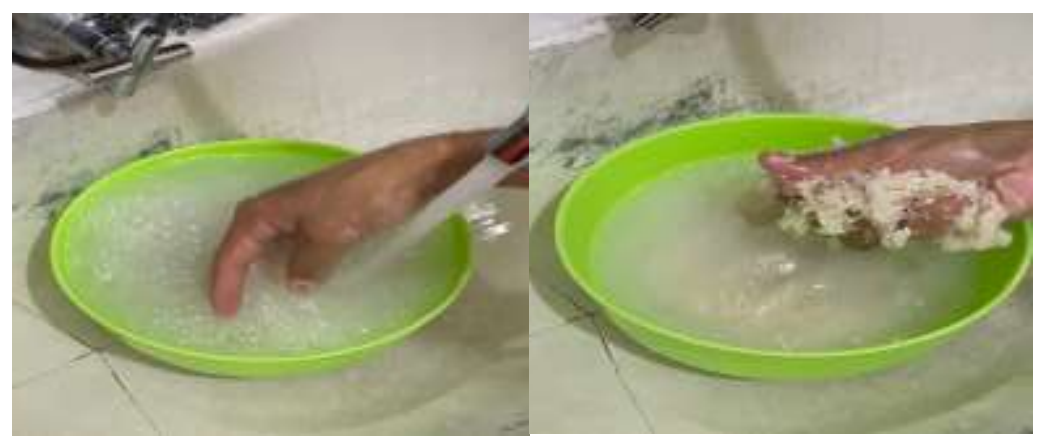

- Tiriskan beras dan letakan ditempat yang sudah disiapkan

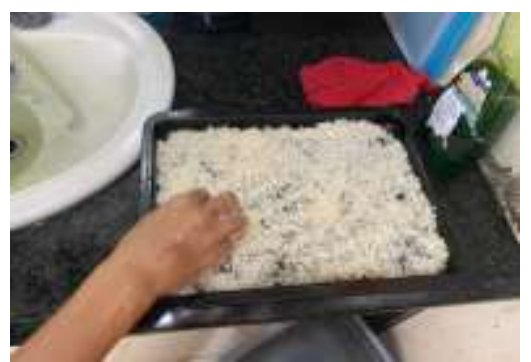

- Kemudian dilakukan pengeringan di bawah sinar matahari. 


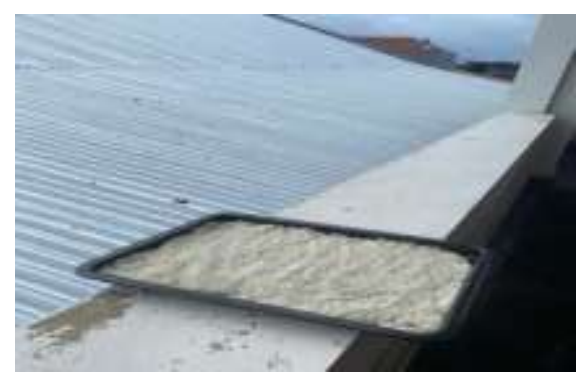

- Setelah beras kering, beras dipindahkan dan siap di haluskan menggunakan blender agar lebih efesien

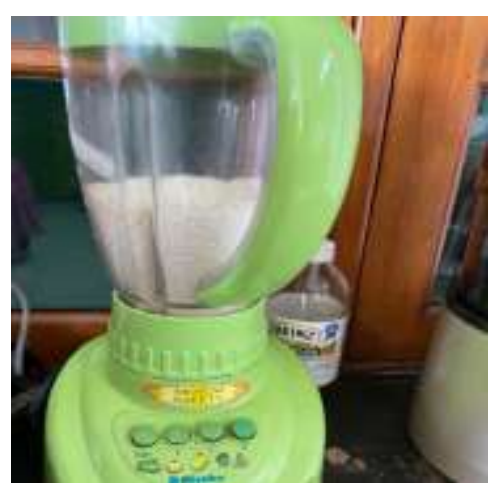

- Setelah proses penghalusan, Tepung beras yang sudah di haluskan dengan tingkat kehalusan sesuai keinginan masing - masing dipindahkan ke dalam wadah yang telah disiapkan

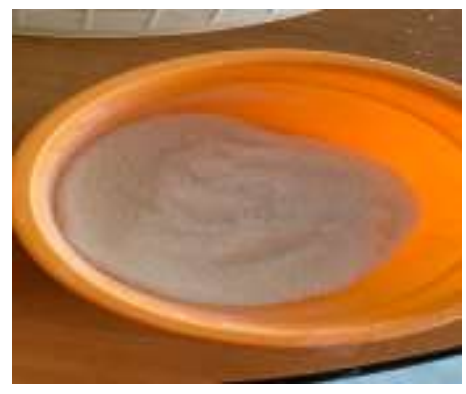

3. Proses Pembuatan bubuk kunyit

- $\quad$ Bersihkan kunyit

Siapkan Kunyit secukupnya setelah itu cuci kunyit hingga kotorannya hilang atau sisa sisa tanah yang terdapat pada kulit kunyit, dibersihkan menggunakan air dengan cara digosok dengan tangan. Setelah proses pembersihan kunyit selesai selanjutnya pengupasan kulit kunyit.

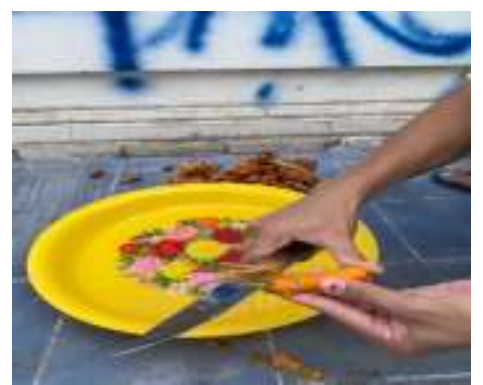

Melakukan pengirisan setipis mungkin pengirisan dilakukan secara tipis-tipis untuk memudahkan proses pengeringan. 


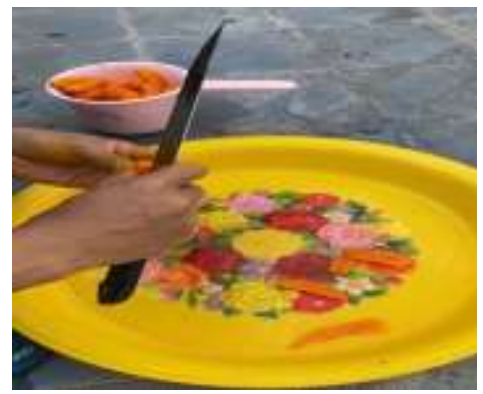

\section{- $\quad$ Penjemuran}

Selanjutnya dilakukan Penjemuran kunyit dilakukan pengeringan di bawah sinar matahari hingga benar benar kering. Waktu Pengeringan tergantung pada teriknya sinar matahari.

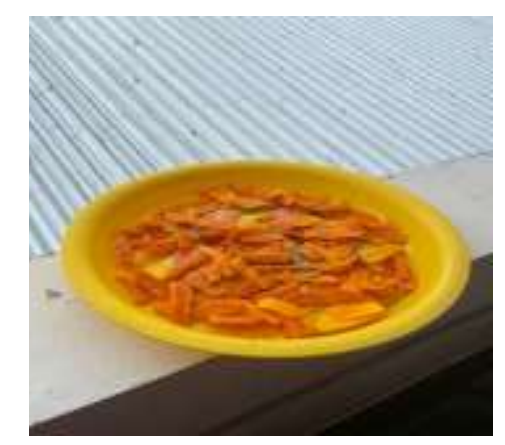

- $\quad$ Penghalusan Kunyit

Setelah kering haluskan Kunyit dengan menggunakan blender agar menghemat waktu.

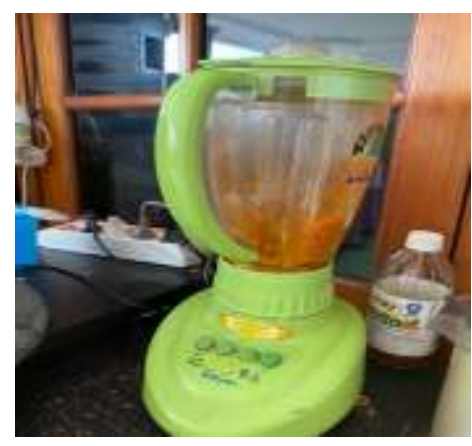

- Setelah proses penghalusan bubuk kunyit yang sudah di haluskan sesuai dengan tingkat kehalusan yang diinginkan lalu dipindahkan ke dalam wadah yang telah disiapkan

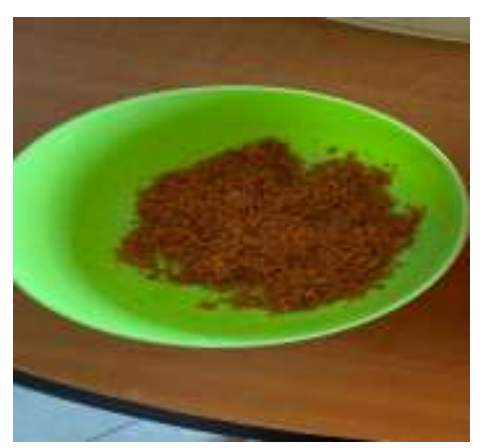


4. Pengemasan Lulur Tradisional

Memilih kemasan lulur tradisional berjenis standing pouch karena standing pouch memiliki keunggulan sebagai kemasan produk, yaitu:

1. Praktis, disertai dengan penutup zipper yang memudahkan konsumen untuk mengambil produk dan menyimpannya kembali dan menjaga kualitas produk yang terdapat produk yang terdapat didalam kemasan

2. Standing pouch ini terbuat dari $80 \%$ Kertas (Kraft) dan $20 \%$ plastik, bahan ini merupakan bahan yang kedap udara sehingga menjaga kualitas produk agar tetap baik

3. Modern dan lebih menarik karena, bentuk kemasan memungkinkan agar bisa berdiri dan memiliki zipper yang terlihat kekinian

4. Harga cukup ekonomis, kemasan ini termasuk keamasan yang tidak memakan banyak biaya dari pengerjaan dan bahannya dengan itu, jika ingin menjual produk dengan harga yang standart dan dapat tetap bersaing

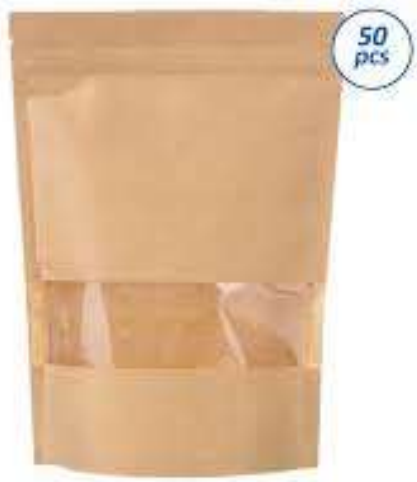

\section{HASIL DAN PEMBAHASAN}

Kegiatan pengabdian kepada masyarakat mengenai pembuatan lulur tradisional dari bahan dasar beras ini yang dilaksanakan di Desa Mas Ubud dan seluruh kegiatan dapat dilaksanakan sesuai dengan jadwal yang direncanakan. Berdasarkan tujuan dari kegiatan pengabdian ini yaitu memberikan pengetahuan mengenai manfaat lain dari beras dan melakukan pelatihan dalam pembuatan lulur tradisional yang dapat memberikan pengetahuan yang baru kepada masyarakat. Mitra telah mampu menghasilkan inovasi baru yang sebelumnya hanya mengetahui beras hanya sebagai makanan pokok masyakarat.

Lulur Tradisional tepung beras dan kunyit yang kami buat ini memiliki tekstur lulur yang kasar berbeda dengan produk lulur lainnya yang bertekstur sangat halus. Tekstur lulur yang kasar lebih efektif digunakan untuk mengangkat sel kulit mati di kulit kita, berbeda dengan tekstur lulur yang sangat halus kurang efektif untuk mengangkat sel kulit mati dam kami membuat produk Lulur tradisional ini berupa bubuk, Lulur ini paling sering dijumpai di pasaran. Bentuknya berupa bubuk, yang terbuat dari bahan-bahan tradisional yang dikeringkan. Lulur tradisional ini dapat dicampurkan dengan bahan lain sebagai bahan perekat lulur yang bisa sesuai dengan kebutuhan dan khasiat yang diinginkan, misalnya dicampur dengan minyak zaitun. Untuk memakainya, lulur jenis ini harus dicampur terlebih dahulu dengan air mineral, air mawar atau minyak zaitun sebelum dioleskan ke tubuh.

Merancang kemasan dan merek. Merancang kemasan yang baik yang memenenuhi standar keamanan produk dan menarik dengan desain yang bagus, mencantumkan merek produk, komposisi bahan, dan izin produksi. Kemasan dirancang dengan model V, Bagian atas menggunakan penutup berbentuk plastic zipper yang berguna untuk mempermudah konsumen untuk membuka dan menutup kemasan. Selain mempermudah konsumen adapun kelebihan 
lainnya yaitu kualitas produk yang ada di dalamnya benar- benar terjaga. Kemasan dilengkapi dengan sticker full color sebagai label, bertujuan agar produk memiliki prestise lebih di mata konsumen, produk menjadi lebih bernilai dan juga lebih aman

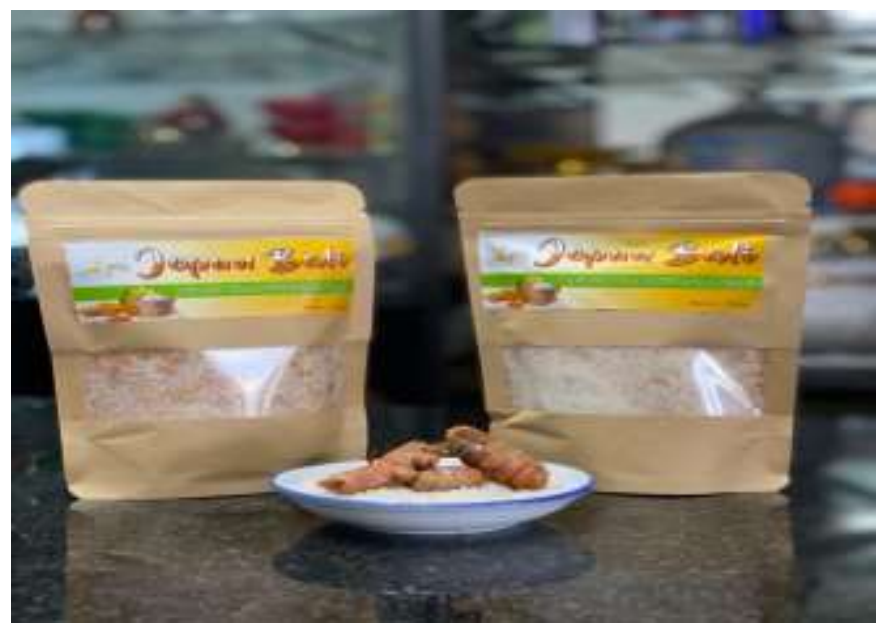

Gambar 2. Hasil produk lulur tradisional berbahan beras dan kunyit

\section{KESIMPULAN}

\subsection{Kesimpulan}

Dalam kegiatan pengabdian kepada masyrakat ini, telah dijelaskan apa saja kandungan yang terdapat pada beras dan kunyit untuk kecantikan kulit. Beras bukan hanya sebagai sumber karbohidrat atau makanan pokok masyarakat Indonesia. Beras dapat digunakan sebagai lulur tradisional. Beras mempunyai fungsi sebagai kecantikan dan kesehatan kulit yaitu meningkatkan produksi kolagen yang bermanfaat untuk membantu meningkatkan kesehatan kulit, memperkuat kulit, elastisitas dan hidrasi pada kulit. Kandungan yang terdapat pada tepung beras adalah gamma oryzanol, kandungan ini memiliki manfaat yang baik untuk kulit sehingga dapat memperbaharui pembentukan pigmen melanin, antioksidan dan efektif untuk menangkal sinar ultraviolet yang membahayakan kulit dan kunyit memiliki manfaat untuk antioksidan, melembabkan kulit, anti inflamasi dan antiseptik yang membantu mengatasi permasalahan jerawat di kulit dan mengatasi pigemntasi (Erlinawati \& Dwiyanti, 2018) dan dapat mencerahkan kulit (Rahmadevi et al., 2020). Adapun efek lainnya yang dapat dirasakan selain dapat mencerahkan kulit dan mengatasi jerawat di kulit, tepung Beras dan bubuk kunyit ini jika dioleskan pada kulit memberikan rasa yang hangat dan dapat membantu melancarkan peredaran darah sehingga baik untuk kesehatan. Banyak wanita yang melakukan perawatan kulit dengan perawatan luluran. Manfaat dari luluran yaitu mengangkat sel kulit mati, mencerahkan kulit, melembapkan kulit, menghaluskan dan melembutkan kulit, mencegah penuaan dini, dan relaksasi. Berdasarkan hasil kegiatan yang dapat disimpulkan:

1. Program pelaksanaan eksperimen pada pembuatan lulur tradisional ini berhasil dilaksanakan dalam mengembangkan potensi petani padi di Desa Mas ubud.

2. Warga telah mengetahui cara pengemasan yang baik, menarik unik untuk menarik daya beli konsumen dan mampu meningkatkan hasil penjualan.

3. Adanya pelatihan pembuatan ide kreatif lulur tradisional ini memberikan manfaat bagi warga yaitu peningkatan pengetahuan dan keterampilan tentang pembuatan lulur tradisional selain digunakan sebagai makanan pokok.

4. Warga dapat menambah penghasilan dengan menjual lulur tradisional dan membantu memperbaiki ekonomi petani padi. 


\subsection{Saran}

Berdasarkan hasil kegiatan pengabdian kepada masyrakat yang telah diperoleh, pelaksanaan pembuatan lulur tradisional tentunya memiliki manfaat yang cukup baik dirasakan oleh warga, karena warga mengetahui inovasi inovasi baru dan menambah wawasan yang sebelumnya warga belum mengetahuinya. Saran yang dapat direkomendasikan adalah sebagai berikut:

1. Untuk kedepannya diharapkan pengabdian yang serupa agar dapat terbentuknya produk -produk baru dari bahan dasar beras agar dapat mengembangkan sektor pertanian.

2. Untuk kedepannya, Masih banyak terdapat jenis bahan alami lainnya yang bisa digunakan sebagai tambahan lulur tradisional dari bahan dasar beras selain kunyit yaitu, contohnya:

- Tepung beras dan Madu

- Tepung beras dan kopi

- Tepung beras dan cokelat

- Tepung beras dan susu

- Tepung beras dan bengkuang dan masih banyak bahan alami lainnya.

\section{DAFTAR PUSAKA}

Aldillah, R. (2016). Kinerja Pemanfaatan Mekanisasi Pertanian dan Implikasinya dalam Upaya Percepatan Produksi Pangan di Indonesia. Forum Penelitian Agro Ekonomi, 34(2), 163. https://doi.org/10.21082/fae.v34n2.2016.163-171

Ayu Putri Chandra, Ameilia Zuliyanti Siregar, H. (2020). Pengendalian Hama Dan Pengolahan Beras Merah. Pengabdian Masyarakat Berkemajuan, 4(November), 513-517.

Bahar, I., Hendri, N., \& Novita, A. (2021). Kemasan Flexible dan Standing Pouch Ditinjau dari Cemaran Mikroba. 2(1), 22-24.

Erlinawati, W. S., \& Dwiyanti, S. (2018). Pengaruh Proporsi Tepung Beras Dan Bubuk Kunyit Putih (Curcuma zedoaria Rosc.) Terhadap Hasil Lulur Bubuk Tradisional. E-Journal, 07(2), 81-87. http://www.ncbi.nlm.nih.gov/pubmed/15003161\%5Cnhttp://cid.oxfordjournals.org/looku p/doi/10.1093/cid/cir991\%5Cnhttp://www.scielo.cl/pdf/udecada/v15n26/art06.pdf\%5C nhttp://www.scopus.com/inward/record.url?eid=2-s2.084861150233\&partnerID=tZOtx3y1

Hariyanto, Rusdi, M., \& Wahyudhi, C. A. (2020). Aplikasi Teknologi Pengering Padi (Rotary Driyer) Kapasitas 2 Ton dengan Bahan Bakar Sekam Padi. 9(3), 1-5.

Meila Sari, E., \& Darmawan, M. M. (2020). Pengukuran Waktu Baku Dan Analisis Beban Kerja Pada Proses Filling Dan Packing Produk Lulur Mandi Di Pt. Gloria Origita Cosmetics. Jurnal ASIIMETRIK: Jurnal Ilmiah Rekayasa \& Inovasi, 2(1), 51-61. https://doi.org/10.35814/asiimetrik.v2i1.1253

Puspitasari, R. D. (2020). Pertanian Berkelanjutan Berbasis Revolusi Industri 4.0. Jurnal Layanan Masyarakat (Journal of Public Services), 3(1), 26. https://doi.org/10.20473/jlm.v3i1.2019.2628

Rachmawati, D., Salim, H., \& Karim, D. (2021). Formulasi Sediaan Lulur Krim Yang Mengandung Tepung Jintan Hitam (Nigella sativa L.) Dengan Variasi Konsentrasi Trietanolamin. Media Farmasi, 16(1), 18. https://doi.org/10.32382/mf.v16i1.1435

Rahmadevi, R., Arin, F., Puspita, O., Firda, A., \& Yasnawati, Y. (2020). Lulur Gosok Tradisional BERSERI (Beras, Serai Wangi, Kunyit) sebagai Antioksidan. Jurnal Abdimas Kesehatan (JAK), 2(3), 190. https://doi.org/10.36565/jak.v2i3.125

Santoso, M. Ramaddan Julianti, A. H. W. (2018). Sistem Pakar Penyakit Padi Menggunakan Metode Certainty Factor Di Desa Giling , Pati Jawa Tengah. Sisfotek Global, 8(2), 2-8.

Trisnawan, A., Harianto, W., \& Syahminan. (2019). Klasifikasi Beras Menggunakan Metode KMeans Clustering Berbasis Pengolahan Citra Digital. Jurnal Terapan Sains \& Teknologi (RAINSTEK) |, 1(1), 16-24. 
Yuliansari Arita, M. P. (2020). Proses Pembuatan Masker Bunga Rosella Dan Tepung Beras Sebagai Pencerahan Kulit Wajah. Jurnal Tata Rias, 09(Vol 9, No 2 (2020)), 367-376. https://jurnalmahasiswa.unesa.ac.id/index.php/jurnal-tata-

rias/article/view/34626\%0Ahttps://jurnalmahasiswa.unesa.ac.id/index.php/jurnal-tatarias/article/view/34627\%0Ahttps://jurnalmahasiswa.unesa.ac.id/index.php/jurnal-tatarias/article/view/34628

Yulmardi, Y., \& Erfit, E. (2018). Daya saing sektor pertanian dalam mendorong pembangunan pertanian di Provinsi Jambi. Jurnal Paradigma Ekonomika, 13(2), 65-76. https://www.onlinejournal.unja.ac.id/paradigma/article/view/6748 